\title{
Clinical features of familial HAM/TSP
}

\author{
Satoshi Nozuma ${ }^{1}$, Eiji Matsuura ${ }^{1 *}$, Toshio Matsuzaki ${ }^{2}$, Osamu Watanabe ${ }^{1}$, Ryuji Kubota ${ }^{2}$, Shuji Izumo², \\ Hiroshi Takashima' \\ From 16th International Conference on Human Retroviruses: HTLV and Related Viruses \\ Montreal, Canada. 26-30 June 2013
}

Some genetic factors are associated with the development of HTLV-1-associated myelopathy/tropical spastic paraparesis (HAM/TSP). So far, there is a very few report about familial HAM/TSP. This study aimed to clarify the clinical features of familial HAM/TSP. We reviewed all patients with HAM/TSP, 784 in number, hospitalized to Kagoshima University Hospital from 1987 to 2012. Familial HAM/TSP cases (patients with one or more HAM/TSP patients in their family) were compared with 124 sporadic HAM/TSP cases (patients with no other HAM/TSP patient in their family) admitted in series for association of clinical features in an unmatched case-control design. As a result, 40 patients $(5.1 \%)$ in total 784 were familial cases. In familial cases compared to sporadic cases, age of onset was earlier (41.3 year old vs. 51.6 year old, $\mathrm{P}<0.001$ ), the number of acute progression cases was smaller (10.0 percent vs. 28.2 percent, $\mathrm{p}=0.019)$, motor disability grade was lower ( 4.0 vs. $4.9, \mathrm{p}=0.043)$ in spite of longer duration of illness (14.3 years vs. 10.2 years, $\mathrm{P}=0.026$ ), and duration between onset and time to use a wheelchair in daily life was longer (18.3 years vs. 10.0 years, $\mathrm{P}=0.025)$ significantly. Protein in cerebrospinal fluid (CSF) was significantly lower in familial cases $(29.9 \mathrm{mg}$ vs. $42.5 \mathrm{mg}, \mathrm{p}<0.001)$. HTLV-1 provirus load, antiHTLV-1 antibody in serum and CSF, cells in CSF was not significantly different. Thus, we demonstrate familial HAM/TSP showing younger onset and slower progress than in sporadic cases. Our results suggest that some genetic factors might influence the incidence of familial HAM/TSP.

\footnotetext{
* Correspondence: pine@m.kufm.kagoshima-u.ac.jp

'Department of Neurology and Geriatrics, Kagoshima University Graduate

School of Medical and Dental Sciences, Kagoshima City, Kagoshima, Japan

Full list of author information is available at the end of the article
}

\section{Authors' details}

${ }^{1}$ Department of Neurology and Geriatrics, Kagoshima University Graduate School of Medical and Dental Sciences, Kagoshima City, Kagoshima, Japan. ${ }^{2}$ Department of Molecular Pathology, Center for Chronic Viral Diseases, Kagoshima University, Japan.

Published: 7 January 2014

doi:10.1186/1742-4690-11-S1-O7

Cite this article as: Nozuma et al:: Clinical features of familial HAM/TSP.

Retrovirology 2014 11(Suppl 1):O7.
Submit your next manuscript to BioMed Central and take full advantage of:

- Convenient online submission

- Thorough peer review

- No space constraints or color figure charges

- Immediate publication on acceptance

- Inclusion in PubMed, CAS, Scopus and Google Scholar

- Research which is freely available for redistribution

Submit your manuscript at www.biomedcentral.com/submit
() Biomed Central 